University of Nebraska - Lincoln

DigitalCommons@University of Nebraska - Lincoln

Faculty Publications, Department of Psychology

Psychology, Department of

March 2003

\title{
Pregnancy, Drug Testing, and the Fourth Amendment: Legal and Behavioral Implications
}

Brian H. Bornstein

University of Nebraska-Lincoln, bbornstein2@unl.edu

Follow this and additional works at: https://digitalcommons.unl.edu/psychfacpub

Part of the Psychiatry and Psychology Commons

Bornstein, Brian H., "Pregnancy, Drug Testing, and the Fourth Amendment: Legal and Behavioral Implications" (2003). Faculty Publications, Department of Psychology. 188.

https://digitalcommons.unl.edu/psychfacpub/188

This Article is brought to you for free and open access by the Psychology, Department of at DigitalCommons@University of Nebraska - Lincoln. It has been accepted for inclusion in Faculty Publications, Department of Psychology by an authorized administrator of DigitalCommons@University of Nebraska - Lincoln. 
Published in Journal of Family Psychology Vol. 17, No.2 (2003), pp. 220-228. Copyright (C 2003 by the American Psychological Association, Inc. http:// www.apa.org/journals/fam/ "This article may not exactly replicate the final version published in the APA journal. It is not the copy of record." Used by permission.

\title{
Pregnancy, Drug Testing, and the Fourth Amendment: Legal and Behavioral Implications
}

\author{
Brian H. Bornstein \\ University of Nebraska-Lincoln
}

\begin{abstract}
In its efforts to protect the health of unborn children, the government is increasingly attempting to regulate pregnant women's conduct. As with other policies affecting pregnant women's autonomy, these policies have constitutional overtones. In Ferguson v. City of Charleston (2001), the Supreme Court struck down a South Carolina hospital's policy of testing pregnant women for cocaine and turning positive results over to law enforcement for prosecution. This article discusses the basis of the decision and its legal and behavioral implications. Although the decision came down on the side of pregnant women's rights, it left unresolved the issue of whether a similar policy could be constructed that would pass constitutional muster. The article concludes with a consideration of the likely effects of, and alternatives to, such a policy.
\end{abstract}

The law regulates family life in a number of ways (Harris \& Teitelbaum, 2000), ranging from its formation (marriage) to its expansion (children) and dissolution (divorce). One of the more contentious debates in this arena concerns issues of parent-child conflict, and the rhetoric grows particularly heated when the child in question has not yet been born.1 The most salient and highly publicized aspect of this debate is, of course, women's right to have an abortion (see generally Bartlett \& Harris, 1998, chap. 6B). Recently, however, the state has also sought to regulate the conflict between mothers and fetuses by attempting to control, through civil and criminal sanctions, pregnant women's use of substances that might harm the fetus (e.g., Bell, 2001; Hodge, 1999).

Advocates on both sides of this issue agree that "there can be no serious dispute that once a woman has chosen to bear a child, the government has a legitimate interest in pursuing policies that will improve the likelihood her baby will be healthy" (Johnsen, 1992, p. 570). Nonetheless, policies that require drug testing, and possibly prosecuting, pregnant women raise serious issues regarding women's constitutional rights. The leading reproductive-rights cases (e.g., Planned Parenthood of Southeastern Pennsylvania v. Casey, 1992; Griswold v. Connecticut, 1965; Roe v. Wade, 1973) focus on pregnant women's right to privacy, as an element of substantive due process, under the Fifth and Fourteenth Amendments. Policies governing drug use during pregnancy have added a new constitutional wrinkle by potentially infringing on pregnant women's rights against unreasonable search and seizure, as guaranteed by the Fourth Amendment. Thus, such policies have

I am grateful to Susan Bornstein and Craig Lawson for their helpful comments and advice concerning this article.

Correspondence: Brian H. Bornstein, Department of Psychology, University of Nebraska-Lincoln, 238 Burnett Hall, Lincoln, Nebraska 68588-0308. Email: bbornstein2@unl.edu significant legal implications, as well as some obvious (and perhaps not so obvious) implications for pregnant women's behavior. This article reviews the Supreme Court's most recent decision on the matter and discusses these implications.

\section{The Supreme Court's Latest Word on Pregnancy and the Constitution}

The U.S. Supreme Court's latest decision affecting pregnant women's rights was handed down in March 2001 (Ferguson v. City of Charleston [hereinafter "Ferguson"], 2001). Between 1989 and 1994, 253 obstetrical patients, who were receiving prenatal treatment at a public hospital operated by the Medical University of South Carolina (MUSC), tested positive for cocaine in tests of their urine that were given as part of their treatment; 30 of them were arrested (Annas, 2001). The tests were conducted by hospital personnel as a means of inducing patients to obtain treatment to minimize harm to the fetus.

The policy, which was developed in consultation with police, (a) established procedures for identifying and testing pregnant patients suspected of drug use; (b ) required that a chain of custody be followed when obtaining and testing urine samples; (c) provided for education and treatment referral for patients who tested positive; (d) contained guidelines for arrested patients who tested positive; and (e) prescribed prosecutions for drug offenses (possession and/or distribution) or child neglect, depending on the stage of pregnancy. Child neglect prosecutions were predicated on South Carolina's recognition that a viable fetus is a person for legal purposes (Whit-

\footnotetext{
${ }^{1}$ The thorny question of whether a fetus is, in fact, a "child" in the sense of a "person" with legally recognized rights is beyond the scope of this article. Although this issue has come up with regard to drug testing during pregnancy (e.g., Whitner v. State, 1997), it is especially relevant to the abortion debate, which is not addressed here.
} 
ner v. State [hereinafter "Whitner"], 1997). Ferguson differs from the majority of cases in which pregnant women have been prosecuted for using drugs because the plaintiffs objected to the policy underlying the drug testing itself and not to the subsequent prosecution.

The plaintiffs/petitioners in Ferguson were 10 of the patients who were arrested. These patients sued the hospital, individual medical personnel, the city of Charleston, and law enforcement officials who helped develop and implement the policy, in a $\$ 3$ million class-action lawsuit. They sued on the grounds that testing for drugs and turning the results over to police for possible prosecution violated their Fourth Amendment right against unreasonable search and seizure, that medical personnel committed the tort of abuse of process in administration of the policy, and that the policy discriminated against minority women (the racial discrimination issue is treated more extensively elsewhere; see Logan, 1999; Roberts, 1991). The federal district court found for the defendants on all claims, and the plaintiffs appealed (Ferguson v. City of Charleston, 1999).

The principal issue on review was "whether the interest in using the threat of criminal sanctions to deter pregnant women from using cocaine can justify a departure from the general rule that an official nonconsensual search is unconstitutional if not authorized by a valid warrant" (Ferguson, 2001, p. 1284). Respondents' defense was twofold: first, that as a matter of fact, petitioners had consented to the searches, and second, that as a matter of law, the searches were reasonable, even if they were unconsented, because they were justified by "special needs." The district court rejected the second defense because the searches were not done by the hospital for independent purposes, but it submitted the factual defense to the jury, which found for respondents. The Fourth Circuit Court of Appeals affirmed, but without reaching the question of consent; rather, the appellate court held that the searches were reasonable as a matter of law under the "special needs" doctrine (Ferguson v. City of Charleston, 1999). On appeal, the U.S. Supreme Court reversed and remanded.

The decision contained a majority opinion authored by Justice Stevens, a concurring opinion by Justice Kennedy that raised a number of important issues, and a dissenting opinion filed by Justice Scalia, joined (in part) by Chief Justice Rehnquist and Justice Thomas.

\section{Majority Opinion}

The majority held that (a) the urine tests were searches within the meaning of the Fourth Amendment and (b) the tests, and subsequent reporting of positive results to the police, were unreasonable searches absent patients' consent. Likening the patients' situation to cases where employees have provided urine samples for drug screening (e.g., Chandler v. Miller, 1997; Griffin v. Wisconsin [hereinafter "Griffin"], 1987; Skinner v. Railway Labor Executives' Association [hereinafter "Skinner"], 1989; Treasury Employees v. Von Raab [hereinafter "Von Raab"], 1989; Vernonia School District $47 J$ v. Acton [hereinafter "Acton"], 1995), the Court argued that "we have routinely treated urine screens taken by state agents as searches within the meaning of the Fourth Amendment even though the results were not reported to the police" (Ferguson, 2001, p. 1287, note 9). For example, the Court has held that blood and urine testing of railroad employees following train accidents is a search (Skinner, 1989), as is the urinalysis of school athletic participants (Acton, 1995). Thus, MUSC's drug testing procedures "were indisputably searches within the meaning of the Fourth Amendment" (Ferguson, 2001, p. 1287).

The heart of the decision lies in the second part of the holding: that the searches were unreasonable. A search and seizure that would otherwise be unreasonable is allowed if the state can show a "special need" apart from a general interest in crime control (e.g., Acton, 1995; Griffin, 1987; New Jersey v. T.L.O. [hereinafter "T.L.O."], 1985). A search need not be supported by either a warrant or probable cause "in those exceptional circumstances in which special needs, beyond the normal need for law enforcement, make the warrant and probable-cause requirement impracticable" (T.L.O., 1985, p. 748).

Under the special-needs doctrine, several cases involving suspicionless drug testing have been upheld involving employees (Skinner, 1989; Von Raab, 1989), students (Acton, 1995; T.L.O., 1985), and probationers (Griffin, 1987). The respondents in Ferguson (2001) sought to justify their search on the same grounds, arguing that the need to protect the health of both mothers and children justified the invasion of petitioners' privacy. However, the majority held that the "special needs" here did not outweigh the invasion of petitioners' privacy, for two principal reasons. First, the invasion of the MUSC patients' privacy was more substantial than in the other specialneeds cases. In the other cases, "there was no misunderstanding about the purpose of the test or the potential use of the test results, and there were protections against the dissemination of the results to third parties" (Ferguson, 2001, p. 1288). For example, the students in Acton (1995) knew why their urine was being tested, and the results were disclosed only to a limited class of school personnel - they were not turned over to the police or used for any internal disciplinary function. The invasion of the Ferguson petitioners' privacy was greater because they did not know that the test results would be disseminated to third parties.

The second reason why the majority found that the specialneeds test failed was the nature of the special need, which in Ferguson (2001) differed from that typically asserted as justification for a warrantless search. In the earlier cases, "the 'special need' that was advanced as a justification for the absence of a warrant or individualized suspicion was one divorced from the State's general interest in law enforcement" (Ferguson, 2001, p. 1289). For example, in Skinner (1989), the tests were designed "not to assist in the prosecution of employees, but rather 'to prevent accidents and casualties in railroad operations that result from impairment of employees by alcohol or drugs"' (p. 1415). In Ferguson (2001), on the other hand, "the central and indispensable feature of the policy from its inception was the use of law enforcement to coerce the patients into substance abuse treatment" 
(p. 1290). The police were heavily involved in designing the policy, and the results could be, and in many cases were, used in criminal prosecutions on drug or child neglect charges. In other words, the searches served no "special" need of the state but merely the state's general interest in reducing drug use and abuse. As a result, the majority held the following:

Given the primary purpose of the Charleston program, which was to use the threat of arrest and prosecution in order to force women into treatment, and given the extensive involvement of law enforcement officials at every stage of the policy, this case simply does not fit within the closely guarded category of "special needs." (Ferguson, 2001, p. 1292)

\section{Concurrence}

Justice Kennedy's concurring opinion is informative because although he agreed that the hospital's policy was unconstitutional, he also suggested away to make such a policy pass constitutional muster:

As the Court holds, the hospital acted, in some respects, as an institutional arm of law enforcement for purposes of the policy. Under these circumstances [italics added], while the policy may well have served legitimate needs unrelated to law enforcement, it had as well a penal character with a far greater connection to law enforcement than other searches sustained under our special needs rationale. (Ferguson, 2001, p. 1294)

In particular, he stressed that the special needs requirement could be satisfied by having less police involvement in designing the policy and more of a therapeutic than a crime-control purpose.

In essence, Justice Kennedy is saying that a testing policy designed by the hospital on its own (i.e., without police assistance), for the express (and not merely the ostensible) purpose of aiding pregnant women and their unborn children, would be acceptable. Importantly, under such a "benign" policy, it would still be permissible for hospital personnel to turn positive results over to police for possible prosecution. He concluded that

We must accept the premise that the medical profession can adopt acceptable criteria for testing expectant mothers for cocaine use in order to provide prompt and effective counseling to the mother and to take proper medical steps to protect the child. If prosecuting authorities then adopt legitimate procedures to discover this information and prosecution follows, that ought not to invalidate the testing. (Ferguson, 2001, p. 1295, italics added)

In other words, one arm of the state (prosecutors) may piggyback its law-enforcement interests onto another arm of the state's (public hospitals) special need, as long as the hospitals did not know beforehand that, or how, prosecutors would use the information.

\section{Dissent}

Although the jury instructions at trial expressly required a verdict in favor of petitioners unless the jury found that they had consented, neither the Fourth Circuit Court of Appeals nor the Supreme Court majority addressed the issue of consent. The
Court of Appeals held that consent was irrelevant because the state's special need justified a search, even an unconsented one, whereas the Supreme Court majority assumed that the tests were performed without the patients' informed consent and thereby found that the special need did not justify an unconsented search. Thus, unlike the trial court, neither reviewing court found the issue of consent to be an important basis for its decision.

Justice Scalia (joined by Justice Thomas and Chief Justice Rehnquist), on the other hand, found consent to be central to the question of the search's constitutionality. The dissenting opinion is important because, like Justice Kennedy's concurrence, it lays the groundwork for potentially upholding similar testing policies in the future. According to the dissent, the heart of the consent issue is the question of to what, exactly, petitioners consented. They clearly consented to provide the urine specimens. However, it is unclear whether they were informed that the tests of the urine would include drug testing, and they almost certainly were not told that positive test results would be reported to the police. The jury instructions referred only to this first level of consent, the taking of the specimens. According to Justice Scalia, if the patients consented to the taking of the specimens, then it follows that they also consented to any conceivable use of the specimens.

His reasoning is based on a line of cases involving the use of lawful, but deceptive, means of obtaining material for purposes other than those represented by the authorities (e.g., Hoffa $v$. United States, 1966; Illinois v. Perkins, 1990). The leading case in this area, Hoffa v. United States (1966), held that "the Fourth Amendment [does not protect] a wrongdoer's misplaced belief that a person to whom he voluntarily confides his wrongdoing will not reveal it" (p. 413). In other words, as long as a defendant voluntarily provides access to some evidence, there is no reasonable expectation of privacy to invade. Applied to the facts in Ferguson (2001), this would mean that by voluntarily providing the urine sample, the petitioners also (unknowingly) consented to its subsequent use against them in criminal proceedings.

Under this approach, because the entire search was reasonable, "the special-needs doctrine is thus quite irrelevant, since it operates only to validate searches and seizures that are otherwise unlawful" (Ferguson, 2001, p. 1299). Moreover, Justice Scalia finds no difference between the MUSC policy and other circumstances - upheld as constitutional - in which health care professionals are ethically or legally required to disclose information concerning a patient's crime that they encounter in the course of ordinary medical procedures (see, e.g., Annas, 2001; Hall, 1985).

\section{Creating a Constitutionally Acceptable Testing Policy}

The opinion leaves an important issue unresolved: Is a policy like that of the MUSC hospital unconstitutional per se, or could such a policy be modified so as to make it acceptable to the courts?

As one commentator noted, "Substance abuse by pregnant women is not so much a criminological problem, but rather a public health dilemma" (Brody \& McMillin, 2001; see also 
Howell, Heiser, \& Harrington, 1999). Despite the Ferguson (2001) decision, the magnitude of the public health issues involved is likely to produce considerable pressure on states to develop a constitutionally acceptable procedure for testing, and potentially prosecuting, pregnant women for drug use. Evidence that the issue is not simply going to go away comes from several sources. A few state legislatures have attempted to pass legislation criminalizing prenatal drug use, and at least one state (Massachusetts) has successfully enacted such a statute (Mass. Gen. Laws Ann. Ch. 119, § 51A, 1990). When drug use during pregnancy is not an independent crime, women have been prosecuted for child abuse, neglect, vehicular homicide, encouraging the delinquency of a minor, involuntary manslaughter, drug trafficking or delivery of a controlled substance, failure to provide child support, and assault with a deadly weapon (Logan, 1999). As of 1992, 24 states had brought criminal charges against women for using illicit drugs while pregnant (Logan, 1999). In addition, some states provide for civil sanctions, such as the involuntary commitment of pregnant women who appear intoxicated or who fail to complete substance abuse treatment (Brody \& McMillin, 2001; Roberts, 1991).

As of 1999, at least 13 states required public hospitals to test pregnant women who were suspected of drug abuse, with the results reported to social services or the police (Logan, 1999). Prior to the Ferguson (2001) decision, officials from South Carolina - the state that has gone to the greatest lengths in protecting the unborn from maternal drug use"state[d] that they [would] find a way to continue the policy, no matter how the Court rules" (Bell, 2001, p. 657, citing a segment from Nightline: "How Far Can You Go to Protect an Unborn Child?" ABC television broadcast, September 27, 2000). It therefore seems clear that pregnant women will be subject to similar policies in the future. Is there a way for states to make such policies constitutional? As discussed above, Justice Kennedy's concurrence articulated one criterion - a bona fide special need, to which law enforcement is clearly secondary - necessary for a policy similar to the one employed by MUSC to be constitutional. The majority's opinion implied several other conditions that would also be desirable, if not necessary, for the Supreme Court to find such a policy acceptable: private agents, explicit consent, and the elimination of discretionary testing.

The majority stated that "because MUSC is a state hospital, the members of its staff are government actors, subject to the strictures of the Fourth Amendment" (Ferguson, 2001, p. 1287). By implication, a private hospital - as a nongovernmental entity - would not be subject to the same Fourth Amendment restrictions. For instance, a religious hospital that received no state funds could test its patients for drugs, without their consent, and turn the results over to the police. Although such a scenario is theoretically possible, it is highly improbable. Very few hospitals these days are entirely free of governmental funding. Additionally, even hospitals that do not receive direct governmental support must invariably receive indirect funding, in the form of Medicare and Medicaid reimbursement, which the government could use to hold them to certain guidelines, such as rules against unreasonable searches and seizures. Thus, it would seem to make little difference, practically speaking, that MUSC is formally a state-funded institution.

Two procedural variations could still increase the chance of a hospital's successfully implementing a drug-testing policy. First, the policy could require that patients explicitly consent to giving the police access to their test results. Making patients aware of the adverse use to which their test results might be put would almost certainly lead some patients not to seek prenatal care (see below), thereby defeating the purpose of having the policy in the first place. Nonetheless, some patients would likely be so desirous of care, or confident that their test results would be negative, that they would continue to receive prenatal care even though it entailed providing a urine specimen for testing and possible prosecution. Under these circumstances, some women who wished to beat their addiction but were unable to do so might even consent to testing as a "cry for help," in order to commit themselves to maintaining better prenatal health under the threat of prosecution.

Second, although Ferguson (2001) does not say so specifically, a less discretionary policy would almost certainly fare better on review. Because hospital personnel used nine criteria in deciding whom to test, they exerted a great deal of discretion. Previous special-needs cases dealing with suspicionless search or seizure (e.g., Skinner, 1989) have emphasized the importance of implementing procedures with as little discretion as possible, such as random testing. This nondiscretionary approach is preferred within the public-health arena as well. For example, in upholding the mandatory testing of convicted prostitutes for AIDS, the Illinois Supreme Court in People v. Adams (1992) found it highly significant that the statute afforded the court no discretion in determining whom to test. In contrast, Ferguson (2001) noted that respondents did not "point to any evidence in the record indicating that any of the nine search criteria was more apt to be caused by cocaine use than by some other factor, such as malnutrition, illness, or indigency" (p. 1288, note 10). This lack of evidence meant that the selection criteria were fairly unsystematic. The discretionary nature of the policy in Ferguson is characteristic of drug-screening policies applied to pregnant women (Logan, 1999; Roberts, 1991). Logan's thesis is that this very discretion allows hospital and law enforcement personnel to discriminate against poor and African American women. A policy that mandated testing of all pregnant patients, or all pregnant patients having certain indisputable indicators of cocaine use, would be less problematic.

\section{The Likely Effects of, and Alternatives to, a Ferguson-style Policy}

A policy like the one implemented by MUSC, modified to make it constitutional, would have the obvious benefit —not to be underestimated - of identifying and providing treatment for pregnant drug users, thereby improving both their health and their babies' health. No one disputes that drug use by pregnant women is an important public health problem with substan- 
tial social and financial costs (Bell, 2001; Brody \& McMillin, 2001; Johnsen, 1992), many of which could be alleviated by such a policy. However, a Ferguson-style policy would create some important costs as well, for both the pregnant women affected directly and society as a whole (a detailed discussion of the societal costs is beyond the scope of this article). Thus, it is necessary to consider these costs, as well as alternatives to such a policy.

\section{The Effects of Drug Testing During Pregnancy}

A Ferguson-type policy, if successfully enacted, would have legal, behavioral, and clinical consequences. Legally, there are implications for pregnant women's rights and the responsibilities of health care providers. From a behavioral perspective, requiring pregnant women to undergo drug testing could have an adverse impact on their utilization of services for prenatal care. Finally, such a policy could affect the manner in which mental health clinicians work with pregnant substance abusers.

Legal consequences. There are many instances in which the interests of the unborn fetus conflict with the mother's interests (see generally Bartlett \& Harris, 1998). The successful enactment of a policy along the lines of the one in Ferguson (2001) would have a number of legal ramifications, including the restriction of women's reproductive autonomy, implications for the broader use by pregnant and nonpregnant women (and men) of legal and illegal substances, and imposing a higher duty on all health care providers (relating to both physical and mental health professionals), while involving them to a greater degree in the state's law-enforcement purposes.

Maternal-fetal conflict features most prominently in the abortion debate, but it also appears in situations involving surrogate motherhood, pregnancies that jeopardize the mother's health, and, as here, pregnant women's engagement in activities that are hazardous to fetal health. The central issue is the value to be placed on pregnant women's autonomy and health, weighed against the state's interest in protecting and maximizing fetal life and health (Bartlett \& Harris, 1998; Haugaard, 1998; Johnsen, 1992). Upholding a policy similar to MUSC's would send a clear message that in balancing the state's interest in protecting fetal life and the pregnant woman's interest in her own health and autonomy, the fetus's rights trump the mother's rights.

Interestingly, Ferguson (2001) focuses so much on the Fourth Amendment aspects of the case that it completely neglects another consequence of the drug-testing policy: an infringement on women's right to reproductive autonomy. The opinion cites none of the leading reproductive-rights cases, such as Griswold v. Connecticut (1965), Roe v. Wade (1973), Planned Parenthood of Southeastern Pennsylvania v. Casey (1992), or Stenberg v. Carhart (2000). In this context, it is worth noting that one of the places Griswold located women's right to privacy in making reproductive decisions was precisely in the Fourth Amendment right to be secure from unreasonable searches and seizures. It would be ludicrous, of course, for pregnant women to claim a constitutional right to use illegal drugs. Nonetheless, it is not at all far fetched to imagine how allowing a suspicionless, warrantless, unconsented search for illegal drugs - justified by the need to protect maternal and fetal health - could ultimately lead to permitting a suspicionless, warrantless, unconsented search for legal drugs, such as nicotine and alcohol, that are likewise harmful (see, e.g., DiFranza \& Lew, 1995; Finch, Vega, \& Kolody, 2001; Streissguth, Barr, Sampson, \& Bookstein, 1994).

In considering the plausibility of such a scenario, consider that in order to protect the fetus, pregnant women have been civilly committed, incarcerated, or forced to have cesarean sections against their will (Ehrenreich, 1993; Johnsen, 1992; Roberts, 1991). Conduct for which pregnant women have been punished, on grounds of harming the unborn child, includes drinking alcohol, prescription drug use, and negligent driving (Johnsen, 1992). Where does it end? Restricting or punishing pregnant women for behavior that is legal, albeit harmful to the fetus, could open the door to prosecuting women simply for failure to obtain "optimal" prenatal care. Testing them for illegal drugs is but one step along this slippery slope.

Moreover, as Chavkin (1991) pointed out, a policy that is punitive toward pregnant women does not clearly serve the goals of either limiting fetal exposure to toxins or improving women's parental functioning. Offspring can be affected by exposure of either parent to drugs prior to conception, through drugs' effects on sperm and ova, meaning that arguably any drug user who plans to procreate should be prosecuted for child neglect. With regard to the policy's goal of improving drug-abusing mothers' postpartum functioning and treatment of their children, more supportive and less punitive policies are likely to be more effective, as described in the Alternatives to Punitive Policies section below.

Involving health care personnel in testing pregnant women for possible prosecution expands the scope of their involvement in the criminal justice system, leading to possible conflicts between their duty to patients and their duty to the public welfare (Annas, 2001). The doctor-patient relationship has always been treated as special, and in many ways protected, by the courts; involving physicians in law enforcement would chip away at the special nature of this relationship, undermine patients' trust, and have negative repercussions on the quality of care (Annas, 2001). When only about half of pregnant drug users reveal their drug use to their prenatal provider as it is (Weir, Stark, Fleming, He, \& Tesselaar, 1998), it seems that health care providers would want to avoid strategies making it even less likely for such women to share information relevant to the health of both mother and fetus.

Behavioral consequences. Both sides of the Ferguson (2001) opinion acknowledge that a more explicit policy might lead some patients to feel coerced to consent in order to receive medical care and that it would inevitably lead some patients to avoid needed medical care altogether. Diminished prenatal care of any sort creates its own share of public health concerns (Bell, 2001; Brody \& McMillin, 2001; Haugaard, 
1998; Poland, Dombrowski, Ager, \& Sokol, 1993), leading some commentators (e.g., Sovinski, 1997) to argue that "the lack of adequate prenatal care is more detrimental to the health of the developing fetus than is the mother's use of drugs during pregnancy" (pp. 130-131). Notably, after Whitner (1997) allowed criminal prosecution on child neglect charges for drug use during pregnancy, the number of pregnant women applying to treatment programs in South Carolina declined substantially (Brody \& McMillin, 2001).

It is impossible to know whether specifically requiring patients' consent to drug testing is the primary cause of any decrease in prenatal care, or whether other aspects of the testing procedure are responsible. As discussed above, because the Court in Ferguson (2001), except for Justice Scalia's dissent, avoided the issue of consent, it left the door open to constructing similar policies with or without a consent element. Justice Scalia's dissent notwithstanding, informed consent is such a central feature of modern medical care that it is hard to envision a constitutionally acceptable policy in which patients did not explicitly consent to having their urine samples tested for drugs. The question, then, is whether requiring such consent would make patients less likely to avail themselves of prenatal care services. Although relatively few pregnant women overall abuse illicit drugs during pregnancy (prevalence hovers around 5\%; see Finch et al., 2001; Howell et al., 1999; Jewell \& Russell, 2000; Lester, Boukydis, \& Twomey, 2000), substance abuse is an important determinant of prenatal care. Substance abusers are less likely than nonabusers to obtain adequate prenatal care (Poland, Ager, \& Olson, 1987), and many drug-using mothers report that guilt and shame over their drug use is the leading reason for their avoidance of prenatal care (Chavkin \& Paone, 1991, as cited in Chavkin, 1991).

Poland et al. (1993) asked a sample of 142 low-income women who had recently delivered how they believed drug-using pregnant women would behave if the law were changed to prosecute women who used illicit drugs during pregnancy (no such law existed in Michigan, where the study took place, at the time of the study). Specifically, participants were asked how they believed the law would affect women's seeking prenatal care, having a test for drug use, and seeking drug treatment. Approximately half of the participants thought that women would be less likely to get prenatal care or a drug test, whereas only $10 \%$ believed that such a policy would make these behaviors more likely (the remainder stated that it would make "no difference"). Similarly, more participants thought that the policy would diminish, rather than increase, access to treatment. Interestingly, their opinions were comparable whether or not they themselves used drugs. Although pregnant women's beliefs about a policy's effects might not correspond perfectly to their actual behavior under the policy, these results nonetheless suggest that drug testing pregnant women for a punitive purpose "would further alienate pregnant substance-using women from needed health care" (Poland et al., 1993, p. 202).

Substance abuse is not the only factor associated with prenatal care utilization; a number of other factors influ- ence it as well (Poland et al., 1987). A recent large-scale ( $N$ $=2,828$ mothers) study by Sable and Wilkinson (1999) found that women were less likely to receive adequate prenatal care if during pregnancy they changed living conditions or were homeless; had relationship problems; were arrested; were unable to obtain needed services, such as Aid for Families With Dependent Children (AFDC), Women, Infants, and Children (WIC), or Medicaid; or were stressed. Poland et al. (1987) addressed a somewhat different constellation of factors, but with similar results. They found that women were less likely to obtain prenatal care if they were under- or uninsured; had a negative attitude toward their pregnancy, the importance of prenatal care, or health professionals in general; or were delayed in either suspecting pregnancy or telling others about it.

Race and socioeconomic status are also factors: Minority and low-income women are less likely than White and middle-class women to receive adequate prenatal care (Jewell \& Russell, 2000; Mikhail, 2000). For example, Mikhail (2000), in interviews with 126 African American women with newborns, found that $13 \%$ had not received any prenatal care and that only $51 \%$ had received adequate prenatal care. Not coincidentally, minority and low-income women are especially likely to be subjected to discretionary drugtesting policies during pregnancy (Roberts, 1991), which was true of the patients affected by MUSC's policy as well (Annas, 2001; Logan, 1999).

An analysis of these factors suggests that a policy requiring consent to drug testing is especially likely to interfere with drug-using pregnant women's prenatal care. Requiring consent is likely to magnify their guilt over using drugs (even legal ones widely known to harm the fetus, such as alcohol and nicotine), induce stress, and highlight the risk of arrest and prosecution should they test positive. Thus, although previous research has not explicitly compared the effects of requiring consent versus not requiring consent, there seems to be little doubt that a Ferguson-type policy would have a negative impact on pregnant substance abusers' utilization of prenatal care.

A public-health policy's adverse consequences are an important consideration in balancing the policy's public-health benefits against its invasion of patients' privacy (Whalen $v$. Roe, 1977). Although the Court did not explicitly adopt such a balancing test in Ferguson (2001), it is implicit in the special-needs analysis weighing the state's interests against the patients' protection from unreasonable search and seizure. Because the policy would reduce public health by deterring prenatal care, it would seem to lighten the scale on the side of the state's special need, which consequently might not justify the accompanying invasion of privacy. As such, diminished prenatal care is an important consequence to consider from the possible adoption of a policy that involves drug testing of pregnant women.

Implications for clinicians and public policy. Although the legal implications of Ferguson (2001) are greatest for hospitals and physicians, and of course the pregnant women themselves, Ferguson implicates the professional and legal duties of mental health practitioners as well. Substance use during 
pregnancy is associated with numerous mental health problems, such as major psychopathology, a history of abuse or trauma, and dysfunctional family relationships (e.g., Lester et al., 2000). These characteristics of pregnant substance abusers mean that practitioners, especially those working primarily with substance abusers or young women, are likely to encounter women from this population. Clinicians whose focus is on the mental well-being of their clients might think twice about referring pregnant substance abusers for prenatal care if it entails the risk of prosecution, as prosecution is hardly a boon to clients' mental health.

Moreover, what would a clinician's obligation be in the face of clear evidence of drug abuse by a pregnant client? If the mother herself can be found negligent for causing prenatal injury to her offspring (e.g., Grodin v. Grodin, 1980), then it seems that under the Tarasoff (Tarasoff v. Regents of University of California, 1976) duty-to-warn standard, a psychologist treating a pregnant woman for substance abuse could also be held negligent if she knew of the risk to the unborn child and failed to report it to the authorities. Thus, although the legal implications of Ferguson (2001) apply most directly to hospitals and physicians, their mental health brethren-who are equally involved in diagnosing and treating substance abuse-are hardly immune.

\section{Alternatives to Punitive Policies}

Because of the substantial costs and repercussions of prenatal drug use - for newborns, mothers, and society at large - it is important to devise methods of decreasing this hazardous behavior. According to Johnsen (1992), government policies for improving the health of newborns can be categorized as either "adversarial" or "facilitative." Adversarial policies "assume that the government's role is to protect the fetus from the woman," whereas facilitative policies, rather than punishing women for their behavior, "seek to expand women's choices by, for example, improving access to prenatal care, food, shelter, and treatment" (Johnsen, 1992, p. 571). The Ferguson (2001) policy is adversarial in the sense that women who fail to obtain treatment are liable to criminal prosecution; yet such mandatory treatment for drug use in general is not particularly effective (Chavkin, 1991; Haugaard, 1998). The high likelihood of diminished prenatal care suggests that policies that impose mandatory treatment, under threat of punishment, may not have their intended salutary effect. Are there better alternatives?

A number of studies have shown that facilitative policies are more effective at promoting healthy pregnancies among drug-dependent women (Johnsen, 1992). In direct contrast to punitive policies, treatment programs that reward patients for abstinence can reliably reduce drug abuse in pregnant women (Silverman, Svikis, Robles, Stitzer, \& Bigelow, 2001), although the incentives must be substantial (Jones, Haug, Stitzer, \& Svikis, 2000). Interestingly, treatment programs that provide enhanced prenatal care are particularly effective at reducing substance abuse during pregnancy (Corse \& Smith, 1998). Because punitive policies themselves diminish utilization of prenatal care (Poland et al., 1987), any deterrent effect they might exert on drug use is therefore offset by their indirect effect of minimizing the ability of prenatal care to mediate substance abuse treatment effects.

Corse and Smith's (1998) findings suggest that to be effective, substance abuse treatment for pregnant women must do more than merely address the substance abuse itself. Several studies have shown that programs providing "one-stop shopping” (McMurtrie, Rosenberg, Kerker, Kan, \& Graham, 1999) are especially effective in treating this population. Such "holistic" or "comprehensive" treatment programs share several characteristics (Comfort \& Kaltenbach, 2000; Howell et al., 1999; Lester et al., 2000; McMurtrie et al., 1999; WhitesideMansell, Crone, \& Conners, 1999). They

- provide family-centered services, such as day care for older children, parenting and formal educational instruction, and nutritional assistance;

- promote mothers' self-esteem, life skills, coping, and general mental health;

- are community based and are culturally and linguistically sensitive; and

- address other needs, such as transportation, nutrition (e.g., AFDC or WIC assistance), employment, and housing.

Although these sorts of programs have not been directly compared with more punitive or adversarial approaches, the characteristics they contain are predictive of successful treatment outcomes (Comfort \& Kaltenbach, 2000) and exemplify the facilitative approach to treating substance abuse during pregnancy (Johnsen, 1992).

\section{Testing Without Punishing: A Compromise}

Obviously, for any policy to be effective, women who use drugs during pregnancy must first be identified. Because patients are often reluctant to self-report prenatal drug use (Weir et al., 1998), a successful policy is likely still to require a testing component, in order to identify pregnant patients at risk. As with any other medical procedure, patients should provide their consent, not merely to providing a urine (or blood) specimen but also to its being tested for illicit substances. The Ferguson (2001) decision seems to entail also informing patients that positive test results will be turned over to the authorities, but requiring patients to consent explicitly to possible prosecution is unlikely to enhance their continued utilization of prenatal care (Poland et a1., 1993).

Rather, for such a policy to serve the health needs of both mother and child, patients should explicitly be told that positive test results will not entail the chance of prosecution. Because such a policy would have a more clearly therapeutic than law-enforcement purpose, it would be consistent with the sort of acceptable policy outlined by Justice Kennedy in his Ferguson (2001) concurrence. In addition, it would facilitate patients' access to both prenatal care and substance abuse treatment, and it would not pit the interests and responsibilities of patients and providers against each other. Under this procedure, testing could be allowed, and most importantly, at- 
risk patients could be identified for interventions without deterring them from needed prenatal care.

\section{Conclusion}

Ferguson v. City of Charleston (2001) is an important case in the family law domain because MUSC's policy of testing pregnant women for illegal drugs raises issues at the intersection of public health and constitutional law. The public-health aspects concern the very real and significant risks to maternal, fetal, and societal well-being of drug use during pregnancy; in addition, the policy raises constitutional questions about what constitutes a reasonable search and seizure and women's privacy right to reproductive autonomy. Ultimately, the case addresses how best to strike the sometimes competing interests between mothers and their unborn children.

Although the policy was discontinued before the Supreme Court's ruling and the Court held the policy to be unconstitutional, all the components of the decision-majority, concurring, and dissenting opinions - point to ways in which a similar policy could be designed so as to avoid the constitutional pitfalls encountered by the policy in Ferguson (2001). The petitioners won, but their victory is likely to be short lived. Recent developments in a number of states, combined with ongoing public concern about drug abuse, especially by pregnant women, suggest that despite Ferguson's outcome, pregnant women should not feel too secure from state intervention when receiving prenatal care. Such interventions are likely to have significant consequences for pregnant women's legal rights, as well as for their health, their fetuses' health, and their behavior during pregnancy.

\section{References}

Annas, G. J. (2001). Testing poor pregnant women for cocaine: Physicians as police investigators. New England Journal of Medicine, 344, 1729-1732.

Bartlett, K. T., \& Harris, A. P. (1998). Gender and law: Theory, doctrine, commentary (2nd ed.). New York: Aspen Law \& Business.

Bell, H. F. (2001). In utero endangerment and public health: Prosecution vs. treatment. Tulsa Law Journal, 36, 649-676.

Brody, D., \& McMillin, H. (2001). Combating fetal substance abuse and governmental foolhardiness through collaborative linkages, therapeutic jurisprudence and common sense: Helping women help themselves. Hastings Law Journal, 12, 243-272.

Chandler v. Miller, 117 S. Ct. 1295 (1997).

Chavkin, W. (1991). Mandatory treatment for drug use during pregnancy. JAMA, 266, 1556-1561.

Comfort, J., \& Kaltenbach, K. A. (2000). Predictors of treatment outcomes for substance-abusing women: A retrospective study. Substance Abuse, 21, 33-45.

Corse, S. J., \& Smith, M. (1998). Reducing substance abuse during pregnancy: Discriminating among levels of response in a prenatal setting. Journal of Substance Abuse Treatment, 15, 457-467.

DiFranza, J. R., \& Lew, R. A. (1995). Effect of maternal cigarette smoking on pregnancy complications and sudden infant death syndrome. Journal of Family Practice, 40, 385-394.
Ehrenreich, N. (1993). The colonization of the womb. Duke Law Journal, 43, 492-587.

Ferguson v. City of Charleston, 186 F.3d 469 (4th Cir. 1999).

Ferguson v. City of Charleston, 121 S. Ct. 1281 (2001).

Finch, B. K., Vega, W. A., \& Kolody, B. (2001). Substance use during pregnancy in the state of California, USA. Social Science and Medicine, 52, 571-583.

Griffin v. Wisconsin, 107 S. Ct. 3164 (1987).

Griswold v. Connecticut, 85 S. Ct. 1678 (1965).

Grodin v. Grodin, 301 N. W. 2d 869 (Mich. App. 1980).

Hall, M. A. (1985). Hospital and physician disclosure of information concerning a patient's crime. University of Detroit Law Review, 63, 145-182.

Harris, L. J., \& Teitelbaum, L. E. (2000). Family law (2nd ed.). New York: Aspen Law \& Business.

Haugaard, J. J. (1998). Mandated interventions with drug-dependent, pregnant women. Journal of Child and Family Studies, 7, 377392.

Hodge, J. G. (1999). Annotation: Prosecution of mother for prenatal substance abuse based on endangerment of or delivery of controlled substance to child. American Law Reports (5th), 70, 461489.

Hoffa v. United States. 87 S. Ct. 408 (1966).

Howell, E. M., Heiser, N., \& Harrington, M. (1999). A review of recent findings on substance abuse treatment for pregnant women. Journal of Substance Abuse Treatment, 16, 195-219.

Illinois v. Perkins, 110 S. Ct. 2394 (1990).

Jewell, N. A., \& Russell, K. M. (2000). Increasing access to prenatal care: An evaluation of minority health coalitions' early pregnancy project. Journal of Community Health Nursing, 17, 93-105.

Johnsen, D. (1992). Shared interests: Promoting healthy births without sacrificing women's liberty. Hastings Law Journal, 43, 569614.

Jones, H. E., Haug, N. A., Stitzer, M. L., \& Svikis, D. S. (2000). Improving treatment outcomes for pregnant drug-dependent women using low-magnitude voucher incentives. Addictive Behaviors, 25, 263-267.

Lester, B. M., Boukydis, C. F. Z., \& Twomey, J. E. (2000). Maternal substance abuse and child outcome. In C. H. Zeanah (Ed.), Handbook of infant mental health (2nd ed., pp. 161-175). New York: Guilford Press.

Logan, E. (1999). The wrong race, committing crime, doing drugs, and maladjusted for motherhood: The nation's fury over "crack babies." Social Justice, 26, 115 et seq.

Mass. Gen. Laws Ann. Ch. 119, § 51A (West Supp. 1990).

McMurtrie, C., Rosenberg, K. D., Kerker, B. D., Kan, J., \& Graham, E. H. (1999). A unique drug treatment program for pregnant and postpartum substance-using women in New York City: Results of a pilot project, 1990-1995. American Journal of Drug and Alcohol Abuse, 25, 701-713.

Mikhail, B. (2000). Prenatal care utilization among low-income African American women. Journal of Community Health Nursing, 17, 235-246.

New Jersey v. T.L.O., 105 S. Ct. 733 (1985).

People v. Adams, 597 N.E. 2d 574 (III. 1992). 
Planned Parenthood of Southeastern Pennsylvania v. Casey, 112 S. Ct. 2791 (1992).

Poland, M. L., Ager, J. W., \& Olson, J. M. (1987). Barriers to receiving adequate prenatal care. American Journal of Obstetrics and Gynecology, 157, 297-303.

Poland, M. L., Dombrowski, M. P., Ager, J. W., \& Sokol, R. J. (1993). Punishing pregnant drug users: Enhancing the flight from care. Drug and Alcohol Dependence, 31, 199-203.

Roberts, D. E. (1991). Punishing drug addicts who have babies: Women of color, equality, and the right of privacy. Harvard Law Review, 104, 1419-1482.

Roe v. Wade, 93 S. Ct. 705 (1973).

Sable, M. R., \& Wilkinson, D. S. (1999). The role of perceived stress on prenatal care utilization: Implications for social work practice. Health \& Social Work, 24, 138-146.

Silverman, K., Svikis, D., Robles, E., Stitzer, M. L., \& Bigelow, G. E. (2001). A reinforcement-based therapeutic workplace for the treatment of drug abuse: Six-month abstinence outcomes. Experimental and Clinical Psychopharmacology, 9, 14-23.

Skinner v. Railway Labor Executives’ Association, 109 S. Ct. 1402 (1989).
Sovinski, C. J. (1997). The criminalization of maternal substance abuse: A quick fix to a complex problem. Pepperdine Law Review, 25, 107-139.

Stenberg v. Carhart, 120 S. Ct. 2597 (2000).

Streissguth, A. P., Barr, H. M., Sampson, P. D., \& Bookstein, F. L. (1994). Prenatal alcohol and offspring development: The first fourteen years. Drug and Alcohol Dependence, 36, 89-99.

Tarasoff v. Regents of University of California, 551 P.2d 334 (Cat. 1976).

Treasury Employees v. Von Raab, 109 S. Ct. 1384 (1989).

Vernonia School District 47J v. Acton, 115 S. Ct. 2386 (1995).

Weir, B. W., Stark, M. J., Fleming, D. W., He, H., \& Tesselaar, H. (1998). Revealing drug use to prenatal providers: Who tells or who is asked? Drugs \& Society, 13, 161-176.

Whalen v. Roe, 97 S. Ct. 869 (1977).

Whiteside-Mansell, L., Crone, C. A., \& Conners, N. A. (1999). The development and evaluation of a drug prevention and treatment program for women and children: The AR-CARES program. Journal of Substance Abuse Treatment, 16, 265-275.

Whitner v. State, 492 S. E.2d 777 (S.C. 1997), cert. denied, 118 S. Ct. 1857 (1998)

Submitted December 2001;

revised May 2002;

accepted June 24, 2002. 